\title{
INTEGRATIVE LEARNING APPROACH IN ESP/ELP: Theoretical framework of intradisciplinary, multidisciplinary, interdisciplinary, and transdisciplinary integration
}

\begin{abstract}
In English for Specific Purposes (ESP), Integrative Learning has been used in many contexts as a conceptual and structural framework for designing holistic and authentic learning experiences. This approach encompasses many intradisciplinary, multidisciplinary, interdisciplinary and transdisciplinary perspectives. Given the prominent role of English for Legal Purposes (ELP) or Legal English (LE) in legal education, this article explores the theoretical framework of Integrative Learning approach to ELP/LE curriculum design for academic and professional purposes in tertiary education. The first part of the paper presents the conceptual framework of Integrative Learning in contemporary education, legal education and ESP/ELP instruction. The second part examines the conceptual framework and tenets of different (intra/multi/inter/transdisciplinary) approaches to curriculum design. The third part reviews the tenets of the integrated curriculum, as a structural framework for integration of these diverse perspectives, focusing on the major challenges and multidimensional alignments in ELP/LE course design. As integrative learning offers viable solutions for authentic learning in various academic/professional contexts, the paper aims to encourage cooperation in developing integrated law-andlanguage programs and promoting interdisciplinary and transdisciplinary legal education.
\end{abstract}

Keywords: ESP, ELP, Legal English, integrative learning, integrated curriculum, authentic learning.

*goga@prafak.ni.ac.rs 


\section{Introduction}

English for Legal Purposes (ELP) or Legal English (LE) is an areas of English for Specific Purposes (ESP) which has gained prominence in the past decades due to the growing global demand for effective law-and-language instruction. While Legal English has been internationally recognized as an important global legal skill (GLS, 2010), there seems to be insufficient awareness among national stakeholders about its essential role in quality legal education.

Integrative Learning has been used in many contexts as a conceptual and structural framework for designing holistic and authentic learning experiences for discourse community purposes. In ESP/ELP contexts, the integrated curriculum should include the requisite communicative competences, discipline-specific contents, and relevant ESP-specific pedagogy. The multifaceted structure and functions of ESP/ELP instruction inevitably bring into play diverse intradisciplinary, multidisciplinary, interdisciplinary and transdisciplinary perspectives, which are an integral part of the Integrative Learning framework. In the growing ESP literature, the application of this approach in ELP/LE contexts seems to be insufficiently addressed.

This article explores the theoretical framework of integrative learning approach applied in ELP/LE instructional design for academic and professional purposes (LEAP/LEPP) at the Faculty of Law, University of Niš. After presenting the conceptual framework and tenets of integrative learning in general education, legal education and ESP/ELP instruction, the author reviews the conceptual framework of various (intra/multi/inter/transdisciplinary) approaches to curriculum design. Then, the paper focuses on the integrated curriculum, as a structural framework for integration of intra/multi/inter/transdisciplinary perspectives. These insights are the cornerstone for discussing the key challenges and multidimensional alignments in ELP/LE integrated curriculum design. The synergy of diverse perspectives may be a valuable asset in developing integrated law-and-language programs which would foster authentic learning for discourse community purposes and promote interdisciplinary and transdisciplinary legal education.

\section{The Integrative Learning Approach: contemporary trends}

Integrative learning is defined as "an umbrella term for structures, strategies and activities that bridge numerous divides" between theory and practice, formal and informal education, academic and community life (Klein, 2005:8). The integrative approach calls for "the new quadrangulation of disciplinary depth, multidisciplinary breath, interdisciplinary integration and transdisciplinary competences" (Klein, 2008:406). 
The conceptual framework of integrative learning includes a range of related terms, which illustrate its holistic nature. Thus, it entails: a) integrative study programs (inter/transdisciplinary courses/programs, learning communities, project networks); b) integrated curriculum (standards-based, learner/learningoriented); c) integrative pedagogy/methodology (experiential, communicative, collaborative learning); d) integrative processes (reorganization, reconstruction, convergence, transformation); e) integrative forms of instruction (research/ evidence-based, competency/performance-based, process/product-based, problem/project-based) and activities (case studies, simulations); f) integrative competences/ (discourse/genre analysis, critical thinking, problem-solving, decision-making); g) integrative assessment (formal/informal, summative/ formative); h) integrative support strategies (learner/learning skills, collaboration, networking, internship/externship); i) integrative sustainable solutions and outcomes for application in real-life contexts (Klein, 1999:16-23; Newell, 2010:8-11).

Therefore, integrative learning is an eclectic and holistic learner/learning-centered approach, aimed at correlating multiple perspectives, cultivating inter/ transdisciplinary mindsets, developing integrated systems of knowledge/competences/values, transferring and applying them in real-world contexts. In that respect, integrative learning is correlated with some other concepts: authentic learning, the 21st century (transferable life) skills, and the global competence.

Authentic learning is an umbrella term for a set of concepts pertaining to natural, practical, meaningful and effective learning in real-life contexts or for real-world purposes. It entails various processes aimed at correlating institutional study with contents, competences, activities, methods, processes and practices actually used in real-world discourse community contexts (GSP, 2013). It includes a set of related concepts, reflecting all stages of course design: authentic approach, learner needs and contexts; authentic goals/outcomes, assessment and evaluation; authentic contents, competences and values; authentic materials and activities; authentic interaction for authentic communication, authentic learning experiences and environments. In ELP/LE, authentic learning activities are genre analysis, mock-trials, moot court simulations, etc.

Within the UN Sustainable Development Agenda (2002), in the field of Education for Sustainable Development (ESD), the UNESCO proposed the 21st Century Learning Framework, which includes the concept of essential 21st century skills, comprising three integrated life skills: 1) Learning skills (critical thinking, problem-solving, communication, collaboration; creativity, innovation, life-long learning); 2) Literacy skills (information/data, media and digital literacy); and 3) Transferable life and career skills (flexibility, adaptability, accountability, pro- 
ductivity, self-direction, initiative, leadership, social skills) (UNESCO, 2012:11). It also promoted relevant support systems: curriculum design, instruction, assessment, learning environments, and professional development standards (P21, 2007:1-2). The conceptual framework of integrated learning for sustainable development includes five pillars of quality education: 1) Learning to know; 2) Learning to do; 3) Learning to be; 4) Learning to live with others; and 5) Learning for change and transformation of oneself and society (UNESCO, 2018:90). It entails "competence-based learning" and "action-oriented transformative pedagogy", focused on "interdisciplinarity and transdisciplinarity" (UNESCO, 2018:39-40). In the 2015 UN Sustainable Development Agenda, Goal 4 reinforced the concepts of "inclusive and equitable quality education", "life-long learning", "effective learning environments and outcomes", "qualified teachers and teacher training", and "technical and vocational skills for employment" (UN SDA, 2015:21-22).

The EU strategy framework for promoting global education "for greater justice, democracy and human rights" was initially articulated in the CoE Global Education Declaration (2002). Global education is described as "an interdisciplinary pedagogical approach" to "transformative" learning on global issues (e.g. global citizenship, intercultural cooperation, human rights, conflict resolution); it is aimed at developing the global competence, "a combination" of knowledge, skills, attitudes and values (social literacy, responsible citizenship; critical/ analytical thinking, problem-solving, decision-making, constructive action, cooperation, solidarity, etc.) (CoE, 2019:17-19). The OECD Learning Framework 2030 envisages "a learning compass", depicting four quality learning assets: a) Knowledge (epistemic, procedural, disciplinary, interdisciplinary); b) Competences (cognitive/meta-cognitive, professional, social, interpersonal); c) Attitudes (principles, beliefs, judgment, conduct); and d) Values (personal, professional, local, societal and global); they are to make learners "agents of change" (OECD, 2018:4-5). The framework also envisages an "adaptable and dynamic" integrated learning-centered curriculum, based on the principles of disciplinary rigour, focus, authenticity, alignment, coherence, flexibility, transferability, engagement and choice (OECD, 2018: 6-7).

\subsection{Integrative learning approach in legal education}

In legal education, the prevailing teaching methods in both European-Continental and Anglo-Saxon/American legal tradition used to be the study of legal doctrine (in lectures), the Socratic (questioning) method, and the doctrinal analysis of cases (in tutorials). In the late 19th century, given the observed need for correlating theory and practice, the leading law schools in the UK (Oxford, Cambridge) and the US (Harvard) embarked on introducing "the pedagogies of 
practice" (practical training) into their curricula (Wilson, 2018: 1-2). The 20th century curricular reforms gradually introduced different forms of experiential learning (by doing): legal research and writing, professional practice workshops (advocacy, ethics, rhetoric), debates, role-play, mock-trials, moot court simulations, legal clinics, internships, pro bono services, apprenticeship, etc. (Wilson, 2018:2-4, 8-9). The 21st century globalization trends prompted the inclusion of multi/inter/transdisciplinary programs, new (collaborative, project-based learning) approaches, learning formats (exchange programs, academic/professional networks, E-learning), professional practice formats (online dispute resolution), global skills (negotiation, mediation, leadership).

As the ultimate goal of legal education is to prepare students for professional practice, contemporary law schools endeavour to provide "innovative, integrated, pluralistic" competency-based and outcomes-based curricula with "experiential and differentiated learning" opportunities (Tokarz, Lopez, Maisel, Seibel, 2014: 13,20). In the USA, for example, the integrated curriculum should include four competences essential for legal professionals: a) cognitive competences (legal literacy; knowledge of doctrines, rules, procedures; case method, critical/analytical thinking); b) professional competences (legal research, analysis, interpretation, evaluation, legal writing; lawyer skills, legal argumentation, problem-solving, advocacy; public speaking); c) professional identity and responsibility (values, ethics, conduct, judgment); and d) personal qualities and interpersonal communication competences (time/case management; cooperation, team work, conflict management; pro bono services, etc.) (Munro, 1991:7; Wegner, 2011:14-19). Similarly, the concept of global legal skills (proposed in 2005) includes: professional competences (legal research, reasoning, writing, ethics, advocacy), language competences (legal English), and socio-linguistic, strategic, ethical and intercultural competencies (GLS, 2010). The examples show that this approach aims to enhance professionalism and employability at the (global) labour market.

\subsection{Integrative learning approach in ELT/ESP/ELP}

English Language Teaching (ELT) methodology has generated an array of integrative learning approaches. ${ }^{1}$ All these approaches are aligned with Bloom's Taxonomy of Educational Objectives (1956) and Revised Digital Bloom's Taxonomy (2001), practical tools for assessing learning and performance against the envisaged standards, goals and objectives (GSP, 2014).

1 E.g. Computer-Assisted Learning/CAL, Flipped/Blended Learning, Distance/Online Learning, Mobile Learning, E-Learning: Virtual Learning Environments (VLE), Learning Management Systems (LMS), and "Gamification". 
ESP course design incorporates many of these integrative approaches or their distinctive features (principles, methods, techniques, strategies, instruments and activities). Yet, compared to ELT courses, ESP courses have two distinctive features: authenticity and ESP-specific methodology, which ensure authentic learning for specific discourse community purposes. ESP/ELP learners are exposed to authentic discourse community contents, genre-specific texts, communicative competences, and discipline-specific practices. It brings into play different intradiscipinary, multidisciplinary, interdisciplinary and transdisciplinary perspectives, as well as discipline-specific principles, methods, techniques, strategies, instruments and activities. As all these perspectives have to be integrated into ESP/ELP instruction, it inevitably entails the need to devise integrative ESPspecific pedagogy/methodology. On the whole, the synergy of these diverse dimensions offers a theoretical, methodological and structural framework for integrative learning in various ESP/ELP academic/professional contexts.

\section{The Conceptual Framework of Integration: approaches to curriculum design}

Curriculum is described as "a planned course of study" or "a structured series of courses", aimed at fostering "quality learning". It stipulates the educational policy, standards, philosophy, objectives, approaches and activities in designing, organizing and implementing a course of study or training (UNESCO-IBE, 2013:16-19). Curriculum design is a process of correlating these components into a coherent whole. Yet, there are different approaches to curriculum design, which reflect different degrees of contact, correlation, interaction, fusion and integration.

\subsection{Intradisciplinary approach}

Intradisciplinarity implies the study within one discipline, which commonly includes a number of subdisciplines sharing sets of discipline-based knowledge, competences/skills and values/assets (Miller, 2010:3-6). The conventional institutional curriculum design relies on a discipline-based curriculum, including foundation (core) and specialized courses relevant in a particular field (UNESCOIBE, 2013:23). Thus, legal education includes a range of law-related disciplines (public/private, substantive/procedural, national/international law), while linguistics entails a range of language-related disciplines (phonology, morphology, syntax, semantics, etc.). 


\subsection{Multidisciplinary approach}

Multidisciplinarity implies the study within one discipline supported by insights from other disciplines. It entails "juxtaposing distinctive disciplinary perspectives" (Klein, 2010:16), identifying links, aligning and coordinating perceptions but without a "systemic effort to combine or integrate the disciplines" (Miller, 2010:8). The benefits are "the accumulation of disciplinary perspectives" and resulting applications in the "host discipline" (Thompson, 2010:5), based on the concepts, methods, and instruments devised in the "contributing" disciplines (ESF, 2011:41). A multidisciplinary curriculum offers different courses related to the core discipline (e.g. law) but without incorporating the disciplinary insights into a new a course of study or discipline (OECD/CERI, 1972:59-60). For example, domestic violence may be examined from the perspectives of criminal law, civil law, sociology, psychology. economics, gender studies, etc.

\subsection{Pluridisciplinary approach}

Pluridisciplinarity is "multidisciplinarity with a higher degree of explicit cooperation", aimed at casting more light on an issue through the lens of several disciplines and generating outputs for further action (Davies, Devlin, Tight, 2010:21-22). A pluridisciplinary curriculum includes "clusters" of interrelated disciplines allowing for mutual borrowing or contributions (OECD-CERI, 1972:238). For example, juvenile delinquency may be more comprehensively addressed by relying on: criminology, criminalistics, penology, victimology, sociology; forensic psychiatry, psychology, linguistics; environmental, cultural, media studies, etc.

\subsection{Cross-disciplinary approach}

Cross-disciplinarity is the study of borderline issues "at the intersection of multiple disciplines" (e.g. law and philosophy, politics, economics, society, culture, language), aimed at filling in the knowledge gaps and resolving problems that exceed disciplinary boundaries (ESF, 2011:39). The "cross-fertilization" of correlated disciplines generates "hybrid" cross-disciplinary approaches, by combining theories, standards, data, structures, approaches, methods, instruments and procedures from other disciplines (Klein, 1996:138-139). This approach may generate new sub-disciplines (e.g. sociology of law, sociolinguistics). A crossdisciplinary curriculum entails the inclusion of contents (e.g. civic education, human rights), competences (research methods, academic writing) and values (ethical, social, cultural assets) across different courses in the curriculum, as the cornerstone for interdisciplinary learning (UNESCO-IBE, 2013:15). 


\subsection{Interdisciplinary approach}

Interdisciplinarity entails "the study within multiple disciplines" by "transferring methods from one discipline to another" (ESF, 2011:39). It facilitates collaboration, analysis, synthesis, "clustering", "cross-hybridization", "building bridges" (Klein, 1999:9-16), "convergence", integration of disciplinary perspectives, and "construction" of comprehensive "interdisciplinary knowledge", aimed at generating alternative solutions for real-world problems or more efficient application of available solutions (Klein, 2010:21). For example, the interdisciplinary bridge between education and technology engendered Computer-Assisted Learning (CAL) and E-Learning varieties. In ESP/LE, the integration of linguistic, discourse and pedagogical perspectives generates new ESP-specific methodologies. Other examples of this approach are forensic, gender and environmental studies, where the insights from many natural, technical, social sciences and humanities generate new solutions for the observed problems.

\subsection{Transdisciplinary approach}

Transdisciplinarity is "a higher stage of integration" which "transcends" disciplinary boundaries through "an overarching synthesis", "assimilation" and "systematic unification of knowledge" into "new holistic conceptual frameworks" (Klein, 2010:24-25; Klein, 2015:20), new paradigms and disciplines, or groundbreaking discoveries based on "transformative" problem-based research (ESF, 2011: 40). This approach is vital in resolving "complex, multidimensional, interdependent, non-linear problems", or emerging global issues (e.g. climate change, terrorisms, migrations, etc.) calling for viable solutions and action models (Klein, 2009:47). It entails "social transformation", i.e. "a paradigm shift" in constructing solutions with due consideration to "normative issues and humanistic approach" (Klein, 2009:35-36). In education, it implies moving among, across and beyond disciplines, acquiring generic global competence and transferable life skills, and generating "the unity of knowledge for sustainable development" - a comprehensive body of theoretical, methodological, technical/technological, professional, practical, and ethical knowledge and competences applicable in real-life contexts (Hirsch Hadorn, 2009:1-2).

All these approaches are an integral part of the integrative learning approach. Considering its ample potentials for the "quadrangulation" of intra/multi/inter/ transdisciplinary perspectives (Klein, 2008:406), integrative learning has been the approach of choice in many ESP contexts. This eclectic approach has many benefits: a) great latitude for exploration, experimentation and creativity; b) freedom of selecting, combining, tailoring, and integrating different approaches; and c) variety of options for enhancing motivation and effectiveness of the 
learning process. On the other hand, the alignment and integration of diverse perspectives is quite a challenging task.

\section{Integrated Curriculum: a conceptual framework for integrating diverse perspectives}

Educational literature proposes a range of curriculum design models: a) within a single discipline (fragmented, connected, nestled); b) across disciplines (sequenced, shared, webbed, threaded, integrated), and c) learner-centered models (immersed, networked) (Fogarty, 1991:61). ${ }^{2}$

The Integrated Curriculum Model offers a conceptual and structural framework for the integration of diverse perspectives. Initially proposed as a "differentiated learning" model for gifted students (VanTassel-Baska, 1986), it was developed as a flexible model applicable in different educational contexts. It includes three learning dimensions: a) content dimension: mastery of knowledge across disciplines (in-depth learning); b) process/product dimension: critical thinking and cognitive processes (higher-order thinking, meta-cognition, data processing, construction of knowledge, application of generic/discipline-specific skills); and c) concept dimension: understanding systems of knowledge, exposure to concepts and themes across disciplines to generate knowledge systems (VanTassel-Baska, Wood, 2010:345-346).

Given the lack of practical instruments for integrated curriculum design, Drake and Burns suggest the Know/Do/Be conceptual framework, which focuses on three key questions: a) What should learners know (content knowledge to ensure understanding)?; b) What should learners be able to do (effective performance to be productive members of the community)?; and c) What traits, attitudes and values should learners demonstrate to be responsible members of society? (Drake \& Burns, 2004: 31). This practical tool recognizes the multifaceted nature of integrated learning, which is standards-based, knowledge-based, competence-based and value-based. Yet, in line with the contemporary trends, it may be upgraded with some dynamic verbs (interact, collaborate, act; develop, improve, grow; transform, create, change), which reflect the ideas of global competences, transferable life skills, and education for sustainable development.

\subsection{Considerations in ESP/ELP Integrated Curriculum Design: complexity}

In contemporary education, there is a need for transparent learning standards and outcomes, purposeful learning experiences, accountability and sustainability of learning for the real-world purposes. In ESP/ELP contexts, the complex

2 For more, see: Fogarty, 1991: 61-65. 
structure of the integrated learning approach is embodied in the key stages of the integrated curriculum design: 1) sound teaching pedagogy and methodology; 2) data-based needs assessment/analysis; 3) measurable learning goals and outcomes; 4) authentic texts for text/genre/discourse analysis; 5) syllabus design; 6) material design; 7) lesson planning and learning activities; 8) classroom management; 9) authentic assessment; and 10) course evaluation and reflection (Ignjatović, 2017:575). These structural components clearly illustrate the complexity of the underlying integrative processes.

Given that the integrative approach to ESP/ELP entails a comprehensive alignment and integration of the diverse linguistic, pedagogical, methodological, discursive, psychological, intercultural and ethical perspectives, the integrated curriculum design implies the need to constantly review, rethink, realign and reconstruct the learning contents, outcomes, environments and pedagogy in line with the specific learner needs. In that context, major challenges are reflected in decision-making processes, setting priorities and striking the right balance in terms of different concerns (assumed and evidence-based needs analysis; broad and in-depth knowledge; alignment of goals/outcomes and assessment tools; balanced share of communicative competences; ${ }^{3}$ supportive environment and learner autonomy, etc. As already noted, additional considerations are embodied in the concepts of authentic learning and ESP-specific methodology, which are to ensure relevant, holistic, effective and enjoyable learning for real-life purposes. In order to bridge the gap between education and employment, ESP/ELP course design also has to facilitate the acquisition of the transferable life and career skills, and the global competence.

\subsection{Challenges in the Integrated Curriculum Design: multidimensional alignments}

Integration is a challenging task in "complex, multidimensional and non-linear" systems (Klein, 2009: 47). The integrated curriculum entails multidimensional alignments and integration of different intra/multi/inter/transdisciplinary perspectives, both at the institutional and course level. In this part of the paper, the author attempts to provide a summary account and visual illustration of the scope and structure of integrative processes within the curricular framework of

3 The communicative competence (Hymes, 1971) entails a set of integrated competences: a) linguistic competence (language codes, conventions); b) socio-linguistic competence (socio-cultural, functional and pragmatic rules); c) discourse competence (discourse rules, genres, skills, processes); d) strategic competence (effective communication and learning rules and strategies (Friedenberg, et al., 2003:viii). For more, see: Ignjatovic, 2017: 581-582. 
three ELP/LE courses provided at the Law Faculty in Niš: the introductory ELP course (in I year) and two elective Legal English/LE courses (in III and IV year). ${ }^{4}$

The alignment and integration processes occur within each course and across the three ELP/LE courses, in several forms: a) "triangulation" of knowledge, competences and values on the horizontal scale, and of learning pedagogy (philosophy, acquisition theory), methodology (methods, techniques, processes) and psychology (humanistic learning) on the vertical scale; and b) "quadrangulation" of intra/multi/inter/transdisciplinary perspectives (Klein, 2008:406). These processes are dynamic, ongoing, correlated, concurrent, transferable and transformative. A single intervention into the course design has "a butterfly effect" on other elements; for example, introduction of a competence (e.g. paragraph writing) instantly calls for rethinking the course structure, incorporating relevant input (theoretical, structural, functional and pragmatic tenets of academic writing), distributing it across the course(s), making adjustments (in material design, activities, classroom management), devising relevant assessment tools, etc. Here, the integration processes are illustrated with reference to structures from natural, technical and social sciences.

At the institutional level, the ELP/LE course materials are aligned with the Law Faculty curriculum in terms of covering discipline/subject-specific contents which are studied in the law-related courses. This external institutional (cross-disciplinary and pluridisciplinary) alignment provides for gradual but progressive incorporation of knowledge, competences and values across the three ELP/LE courses, thus ensuring exposure to the key contents that students may encounter in their future professional life. Thus, the LF institutional curriculum may be depicted as a honeycomb structure (Figure 1), where each course (hexagon) is linked to other courses in the institutional framework; concurrently, each hexagon comprises a subset of hexagonal cells, illustrating the intricate design within each course and possible links with other courses across the framework (Fig.1.a). Such structure facilitates the creation of clusters of related disciplines by borrowing and cross-fertilization of disciplinary contents (Fig.1.b), cross-disciplinary extension (Fig.1.c), and pluridisciplinary integration of overlapping contents/competences/values, approaches/methods/strategies, and intra/multi/inter/transdisciplinary perspectives (Fig.1.d).

4 See: Pravni fakultet u Nišu (2020)/ Law Faculty Niš (website): ELP Course Syllabus (compulsory, I year) 2013; Legal English 1 Course Syllabus (elective, III year) 2013; Legal English 2 Course Syllabus (elective, IV year); (accessed 2.7.2020). 


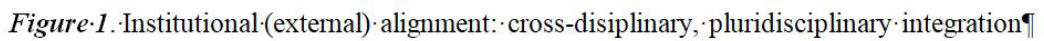

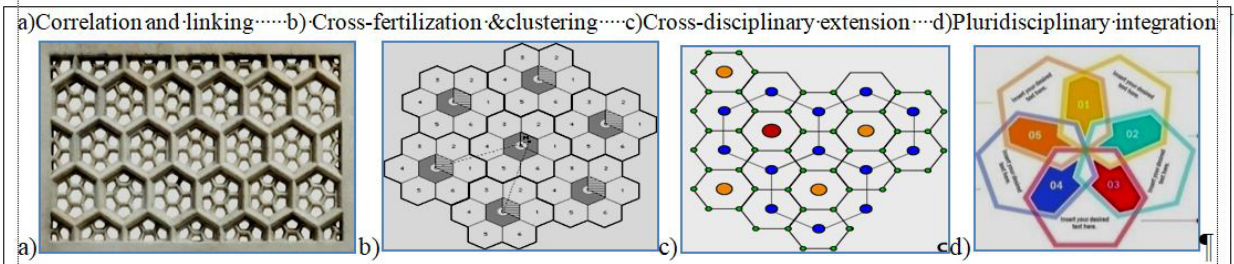

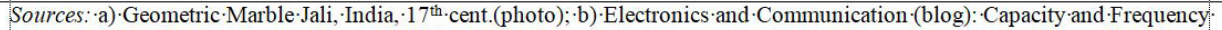

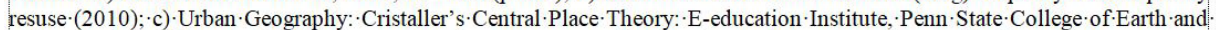

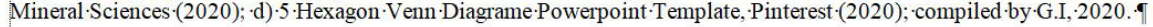

The second dimension of integration implies the internal (intradisciplinary, multidisciplinary, interdisciplinary) alignment within each course. If a course is seen as a single hexagon (Figure 2), it implies the horizontal alignment of contents/competences/values, the vertical alignment of pedagogical/methodological tenets (needs analysis, syllabus/material design; goals/outcomes, assessment; classroom management, learner skills, technology), and the diagonal alignment (cross-referencing) of intra/multi/inter/trans-disciplinary aspects (Fig.2.a) within each course. As hexagons allow for cell-splitting (triangles, rhomboids, hexagons), individual cells may represent manageable chunks for organization and alignment (Fig.2.b), and a blueprint for mapping, clustering, cross-referencing (Fig.2.c), reorganization, reconstruction and reintegration within each course, and alignment with other courses (Fig.2.d). The structure of content sets (knowledge/competences/values) or functional clusters (pedagogy/methodology) within a course may be reused, adjusted or reconstructed for use in other courses (Fig.2.e).

Figure $\cdot 2 \cdot$ Internal-alignment: intradisciplinary, - multidisciplinary $\cdot$ and interdisiplinary $\cdot$ integration $\uparrow$

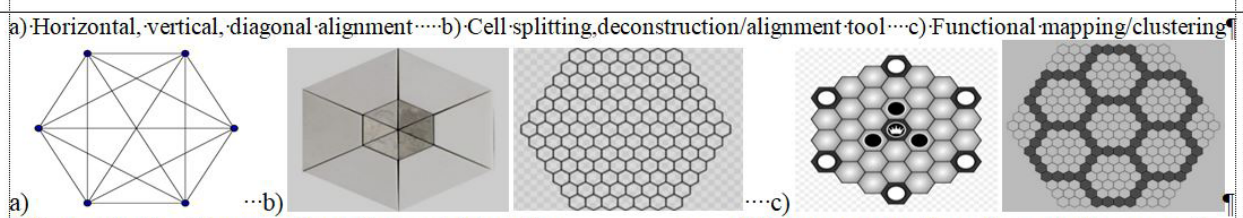

d) Reorganization, Reconstruction, alignment, integration •

) Reuse, reconstruction, adjustment for new $u$ use

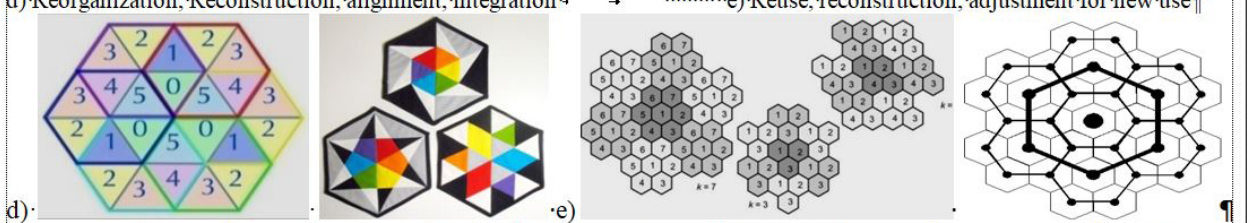

Source $\cdot$ a) $\cdot$ Hexagon $\cdot$ drawing $\cdot 3 \cdot$ line $\cdot$ symmetry, $\cdot$ Ya-Webdesign $\cdot(2018) ; \cdot b) \cdot H e x a g o n \cdot H o n e y c o m b \cdot G e o m e t r y \cdot B e e h i v e \cdot(c l i p \cdot a r t)$,

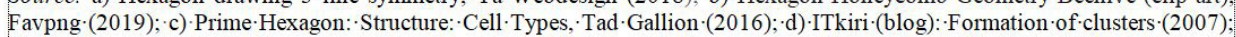
Losch theory, E-education Institute, Penn State-College of Earth and Mineral-Sciences-(2020); compiled by G.I, 2020. $\uparrow$ - 
Yet, if the three ELP/LE courses are observed on a continuum (as a systematic exposure to progressively more complex contents across several courses over a period of time), the 2-D image cannot depict the structural complexity of instruction (length, breadth, depth, volume, density) within each course and across courses. It may be better depicted by a 3-D image, which provides for observing components from different angles (on the horizontal, vertical, diagonal scale, on the cross-sectional plane and on different axes). This pluri-dimensional 3-D alignment, within each course (Figure 3.a) and across courses (Figure 3.b), facilitates a better control of cross-sectional or cross-curricular integration processes and adjustments, while many integration channels provide ample options for alignments and networking across courses (Figure 3.c).

Figure 3. Pluri-dimentional 3-D alignment: intra/multi/inter/transdisciplinary integration within/across courses

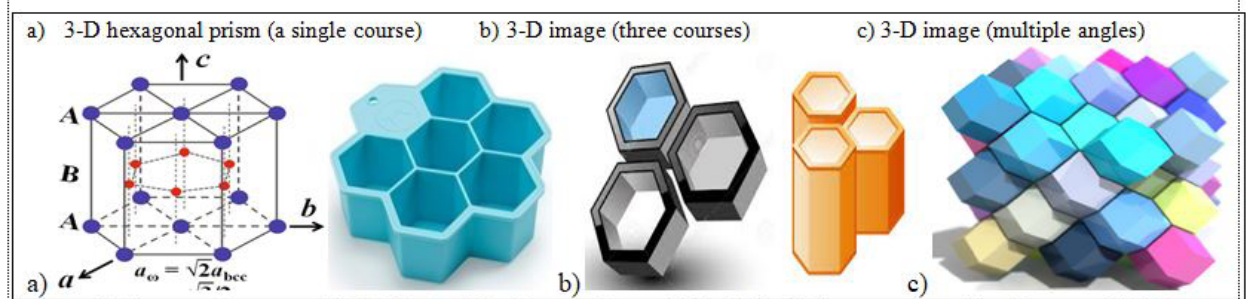

Source: a) A hexagonal structure, P.Dehai, Acta Metallurgica Sinica $(2014,27 / 1)$; b) Honeycom graphics, Vecteezy (2020); c) Hexagonal Cellular Automata, Softology (2020); compiled by G.I, 2020.

The fourth dimension may be described as hyper-dimensional (pluri-directional, transdisciplinary) alignment. As illustrated in natural sciences (Figure 4), multidimensional and non-linear structures (hexagonal grids) are structurally stable and flexible enough to be reshaped into new hyper-structures (spheres, cylinders, toruses, abstract forms). This 4-D alignment offers creative freedom and flexibility to shape complex structures into new forms by: resizing, reconceptualizing, restructuring and reconnecting the contact points; changing the size, length, depth, height; boosting/reducing the mass, volume, density; creating new interfaces, networks and functional models for application in realworld contexts. Such alignment is highly valuable in terms of making the most of multi-dimensional systems and ensuring cross-fertilization, sound balance and functional operation of different dimensions, as well as in terms of keeping the complex structural elements under control, fine-tuning the inconsistencies, ensuring ongoing recalibration and reconstruction for new creative applications. By analogy, all these processes are part of designing the integrated learning curriculum, which may also be shaped into any form, depending on the specific learner/learning needs, goals and purposes. 
Figure 4. Hyper-dimentional alignment: pluri-directional, transdisiplinary integration: shaping new structures

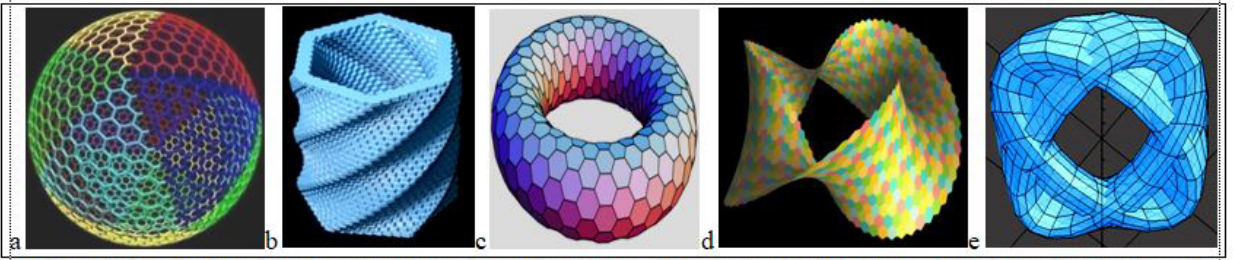

Source: 1) Sphere-shaped hexagonal grid, Stack overflow (blog), Aaron Franke (2017); 2) Fractal Hexagon Cylinder Cup, My mini factury (blog) (2019); 3) Hex grids: torus, abstract shape, 20 Fun Grid Facts (blog), Fun Fact 7, Herman Tulleken (2014);

4) Volume of 3-D torus shape, Jeffry Clark, Mathematics Stack exchange (2015); compiled by G.I (2020)

The 4-D alignment also includes the integration of digital learning, formal/ informal/non-formal learning, experiential learning, immersion into the target community (law clinics, internship, community service), transdisciplinary collaborative projects and experimental research for discovery or innovation. Above all, it entails the transdisciplinary integration of global competences and generic transferable life and career skills, which are essential for ensuring holistic and authentic learning experience for real-world purposes.

\section{Concluding remarks}

The presented theoretical framework of integrative learning and integrated curriculum, with reference to intradisciplinary, multidisciplinary, interdisciplinary and transdisciplinary integration, has been the cornerstone for discussing the integrative processes in ESP/ELP curriculum design for academic and professional purposes in tertiary education. This article is an attempt to provide an insight into the theoretical, pedagogical and methodological tenets of the integrative learning approach applied in three ELP/LE courses provided within the curriculum framework of Law Faculty, University of Niš. Relying on the experience from ELP/LE practice, the author has endeavoured to deconstruct the integration process, discuss its intricate structure and discrete features, and illustrate the multidimensional alignments and integration processes.

In the context of quality education for sustainable development, integrated learning approach offers viable solutions for authentic integrated learning for discourse community purposes. The intrinsically correlated and complementary intra/multi/inter/transdisciplinary perspectives are an integral part of such learning. The author's prior experience in ELP/LE course design for academic/ professional purposes ${ }^{5}$ has proven that these perspectives are a valuable asset in designing and implementing the integrated curriculum. They facilitate an eclec-

5 See: Pravni fakultet u Nišu (2020)/Law Faculty in Niš: ELP Syllabus, LE1 Syllabus, LE2 Syllabus (2.7.2020). 
tic and flexible approach to integration, and a holistic and open-ended approach to learning. This dynamic, adaptable and evolving approach contributes to reducing the clear-cut and often artificially created disciplinary boundaries. It is also liberating as it provides sufficient latitude for adjustments, experimentation and creation of practical learning solutions.

The process of designing an authentic, rigorous, methodologically sound, practical and enjoyable ESP/ELP instruction is a challenging task, which includes multiple considerations. Given the need for transparent learning standards and outcomes, authentic and meaningful learning experiences, accountability and sustainability of quality learning for real-life purposes, the complex structure of the integrated curriculum design in law-and-language contexts entails multiple alignment and integration processes, both at the course and the curricular level: multidimensional (horizontal and vertical, internal and external), pluridimensional (cross-sectional, cross-curricular), and hyperdimensional (pluridirectional, transdisciplinary) alignment.

The past practice has also shown that it is largely up to the ELP/LE practitioner to make sense of ample pathways, align diverse components, and ensure a sound balance of core facets to facilitate authentic learning experiences. In that context, the presented theoretical framework and insights from practice may raise awareness of novice ELP teachers about the challenges encountered in the ELP/LE course design. The author calls for more extensive collaboration of all interested stakeholders (institutions, professional associations, employers, subject-teachers, learners) in the process of developing multi/inter/transdisciplinary law-and-language projects, programs and courses for academic and professional purposes. The contemporary legal education and ESP/ELP trends in integrative learning show that such partnership may be beneficial in many ways. First, it would help overcome the traditional disciplinary boundaries and promote interdisciplinary legal education. Second, it would lead to introducing the much-needed holistic and authentic learning for the discourse community purposes. Third, it would contribute to promoting the transdisciplinary aspects of humanistic education envisaged in the framework of the $21^{\text {st }}$ century global competences and transferable life skills. Last, but not least, it would promote ELP/LE learning and the prominent role of Legal English as a global legal skill.

\section{References}

Davies, M.; Devlin, M.; Tight, M. (eds) (2010). Interdisciplinary Higher Education: Perspectives and Practicalities, Bingley, UK (pp. 2-38); https://philarchive.org/ archive/DAVIHE-4 (accessed 20.10.2019) 
Drake, S. M.; Burns, R. C. (2004). Meeting Standards Through Integrated Curriculum, Association for Supervision and Curriculum Development (ASCD), Alexandria, VA; (24.10.2019) https://repository.stkipgetsempena.ac.id/bitstream/606/1/Meeting_Standards_Through_Integrated_Curriculum.pdf

Fogarty, R.(1991). Ten Ways to Integrate Curriculum, in: Educational Leadership, vol.9, n.2, ASCD, Alexandria, VA, http://www.ascd.org/ASCD/pdf/journals/ed_ lead/el_199110_fogarty.pdf (10.1.2020)

Hirsch Hadorn, G. (ed.) (2009). Unity of Knowledge in Transdisciplinary Research for Sustainability, Vol.I, in: Encyclopedia of Life Support Systems, EOLSS Publishers/UNESCO, Oxford, UK; (pp.1-34); https://www.eolss.net/Sample-Chapters/ C04/E6-49.pdf (retrieved 2.11.2019)

Klein, Julie Thompson (1996). Interdisciplinary Needs: The Current Context, in: Library Trends, Vol.45, No.2, 1996 (pp.134-154), University of Illinois; (retrieved 24.10.2019) https://pdfs.semanticscholar.org/7bb8/6eaddd7bab1176839302b 1089ae848558df1.pdf

Klein, J. Thompson (1999). Mapping Interdisciplinary Studies, in: The Academy in Transition, J.G.Gaff (ed.), AAC\&U, Washington, DC; https://files.eric.ed.gov/ fulltext/ED430437.pdf (20.10.2019)

Klein, J. Thompson (2005). Integrative Learning and Interdisciplinary Studies, in: Peer Review: Integrative Learning, Summer/Fall 2005, vol.7, no.4, (pp.814), American Association of Colleges and Universities https://www.academia. edu/755632/Integrative_learning_and_interdisciplinary_studies (21.10.2019)

Klein, J. Thompson (2008). Education (Chapter 26), In: Handbook of Transdisciplinary Research; eds. G. Hirsch Hadorn, H.Hoffmann-Riem, S.Biber-Klemm, W.Grossenbacher-Mansuy, D.Joye, Ch.Pohl, E. Zemp, U.Wiesmann, Springer; https://link.springer.com/book/10.1007/978-1-4020-6699-3 (1.11.2019)

Klein, J. Thompson. (2009). Unity of Knowledge in Transdisciplinary Research for Sustainability, Vol. I, in: Encyclopedia of Life Support Systems, ed. G. Hirsch Hadorn, EOLSS Publishers/UNESCO, Oxford; https://www.eolss.net/SampleChapters/C04/E6-49-01.pdf (retrieved 2.11.2019)

Klein, J. Thompson (2010). Taxonomy of Interdisciplinarity, in: Oxford Handbook of Interdisciplinarity, eds. R.Frodeman, J.T.Klein, C.Mitcham, (Ch.2, pp.15-30), Oxford University Press; (20.10.2019) https://msu.edu/ orourk51/860-Phil/ Handouts/Readings/Klein-TaxonomyOfInterdisciplinarity-OUP_HoI-2010.pdf

Klein, J. Thompson (2015). Interdisciplining Digital Humanities: Boundary Work in an Emerging Field, (Chapter 1: Interdisciplining (pp. 14-36). University of 
Michigan Press, 2015; (accessed 20.10.2019); https://www.jstor.org/stable/j. ctv65swxd.6?seq=1\#metadata_info_tab_contents

Larsen-Freeman, D.; Anderson, M. (2011). Techniques \& Principles in Language Teaching, OUP

Miller, R. C.(2010). Interdisciplinarity: Its Meaning and Consequences, in: Oxford Research Encyclopedia https://oxfordre.com/internationalstudies/ view/10.1093/acrefore/9780190846626.001.0001/acrefore-9780190846626-e92?print=pdf; (retrieved 10.10.2019)

Munro, Gregory S. (1991). Integrating Theory and Practice in a CompetencyBased Curriculum: Academic Planning at the University of Montana School of Law, 52 Montana Law Rev. (1991). University of Montana, http://scholarship. law.umt.edu/mlr/vol52/iss2/7 (accessed 19.1.2020).

Newell, W.H. (2010). Educating for a Complex World: Integrative Learning and Interdisciplinary Studies, In: Liberal Education,Vol.96(4), AAC\&U, Wash.,DC; https://www.researchgate.net/publication/260675213

Thompson, Grahame (2010). Disciplinarity, Cross-Disciplinarity and 'Performan$c e^{\prime}$, Working paper 70, International Center for Business and Politics, Copenhagen Business School, Frederiksberg, Denmark; https://research.cbs.dk/ files/58951494... (retrieved 10.11.2019)

Tokarz, K.; Lopez, A.S.; Maisel, P.; Seibel, R.F. (2014). Legal Education at a Crossroads: Innovation, Integration, and Pluralism Required! in: Wash.Uni.Journal of Law \& Policy, Vol.43/2014; (10.1.2020) https://openscholarship.wustl.edu/ cgi/viewcontent.cgi?article=1782\&context=law_journal_law_policy

VanTassel-Baska, J.; Wood, S. (2010). The Integrated Curriculum Model, in: Learning and Individual Differences, 20 (2010), 345-357, Elsevier Inc. https:// www.academia.edu/14566179...(10.1.2020)

Wegner, J. W.(2011).The Carnegie Foundation's Educating Lawyers: Four questions for Bar Examiners, in: The Bar Examiner, June 2011 (Vol.80,no.2), Madison, WI; (retrieved 20.1.2020); https://thebarexaminer.org/wp-content/uploads/ PDFs/800211_Wegner.pdf

Wilson, Richard J. (2018).The Global Evolution of Clinical Legal Education: More Than a Method, CUP Cambridge University Press; https://papers.ssrn.com/sol3/ papers.cfm?abstract_id=3424111 (19.1.2020)

Ignjatović, Gordana (2017). Multiple Intelligences in ELP Instruction in Tertiary Education: Integrated Communicative MI-based Activities in Adult ELP/LE Classrooms, In: The Journal of Teaching English for Specific and Academic Purposes, 
Vol.5, No.3, 2017(pp.567-587); (accessed 20.1.2020) http://espeap.junis.ni.ac. rs/index.php/espeap/article/view/569

\section{Institutional sources}

CoE (2002): Maastricht Global Education Declaration: European Strategy Framework for Improving and Increasing Global Education in Europe to the year 2015, Council of Europe, 2002; (19.2.2020).

CoE (2019): Global Education Guidelines: Concepts and methodologies on global education for educators and policy makers, North-South Centre of the CoE, Lisbon (eds. A.Cabezudo, F.Cicala, M.L.de Bivar Black, M.C.da Silva, 2019); https:// rm.coe.int/prems-089719-global-education-guide-a4/1680973101

ESF (2011): European Science Foundation, European Peer Review Guide: Integrating Policies and Practices into Coherent Procedures: A report by ESF (C.Marras, F.Ranjbaran); (24.10.2019) http://www.esf.org/fileadmin/user_upload/esf/ European_Peer_Review_Guide_2011.pdf

GLS (2010), Global legal Skills Conference 2010 program, (accessed 17.1.2020) https://sites.google.com/site/globallegalskillsconferencev/system/app/pages/ subPages?path=/home

GSP (2013): Great School Partnership: The Glossary of Education Reform (online): Authentic Learning (Sept. 2013); https://www.edglossary.org/authentic-learning/ (accessed (17.1.2020)

GSP (2014): Great School Partnership: Glossary of Educational Reform: Bloom's Taxonomy of Educational Objectives, Revised Bloom's Taxonomy, https://www. edglossary.org/blooms-taxonomy/;

OECD (2018): The Future of Education and Skills, OECD Education 2030, Position paper, OECD, Paris https://www.oecd.org/education/2030/E2030\%20 Position\%20Paper\%20(05.04.2018).pdf; (19.2.2020)

OECD-CERI (1972). Interdisciplinarity: Problems of Teaching and Research in Universities (report), eds. L.Apostel, G.Berger, A.Briggs, OECD Centre for Educational Research and Innovation, OECD, https://files.eric.ed.gov/fulltext/ED061895. pdf (10.10.2019)

OECD (2020). Learning Compass 2030, https://www.oecd.org/education/2030project/teaching-and-learning/learning/

P21 (2007). Framework for 21st Century Learning, Partnership for 21st Century Learning (posted 2019), http://static.battelleforkids.org/documents/p21/ P21_framework_0816_2pgs.pdf; (17.1.2020) 
Pravni fakultet u Nišu (2020)/Law Faculty Niš: Nastavni plan Engleski jezik (2.sem) 2013 (ELP Course Syllabus, I), http://www.prafak.ni.ac.rs/files/silabusi/ osnovne/engleski-jezik.pdf; Nastavni plan Engleski jezik pravne struke 1, 2013 (Legal English 1, III), http://www.prafak.ni.ac.rs/files/silabusi/osnovne/engstruke-1.pdf; Nastavni plan Engleski jezik pravne struke 2, 2013, (Legal English 2), http://www.prafak.ni.ac.rs/files/silabusi/osnovne/eng-jezik-struke-2.pdf, (accessed 2.7.2020)

UNESCO (2012): Shaping the Education of Tomorrow: 2012 Report on the UN Decade of Education for Sustainable Development (abridged), UN Educational, Scientific and Cultural Organization, Paris; https://sustainabledevelopment. un.org/content/documents/919unesco1.pdf; (retrieved 19.2.2020)

UNESCO (2018). Issues and trends in Education, A. Leicht, J. Heiss and W. J. Byun (eds), UNESCO, Paris, France; https://unesdoc.unesco.org/ark:/48223/ pf0000261445 (accessed 19.2.2020).

UNESCO-IBE (2013). International Bureau of Education:Glossary of Curriculum Terminology (1.9.2019) http://www.ibe.unesco.org/fileadmin/user_upload/ Publications/IBE_GlossaryCurriculumTerminology2013_eng.pdf

UN SDA(2015): Transforming our World: The 2030 Agenda for Sustainable Development, UN GA Resolution A/Res/70/1, NY, 2015; https://sustainabledevelopment.un.org/content/documents/21252030.

Online sources: inter/transdisciplinary law course, programs, projects (accessed 25.9.2020)

EC (2020):European Commission: Online Dispute Resolution, https://ec.europa. eu/consumers/odr/main/...

EJTN (2020): European Judicial Training Network, http://www.ejtn.eu/;

HLS (2020): Harvard law School: https://hls.harvard.edu/dept/academics/degree-programs/special-programs/;

SLS (2020): Stanford Law School: https://law.stanford.edu/education/only-atsls/interdisciplinary-learning/

NYU Law News (2017): Law workshop for scientists, engineers, physicians, and entrepreneurs 


\title{
Gordana Ignjatović,
}

Predavač engleskog jezika struke,

Pravni fakultet, Univerzitet u Nišu

\section{INTEGRATIVNI PRISTUP UČENJU ENGLESKOG JEZIKA}

PRAVNE STRUKE (TEORIJSKI OKVIR): Intradisciplinarni, multidisciplinarni, interdisciplinarni i transdisciplinarni aspekti

\begin{abstract}
Sažetak
U radu se razmatra teorijski okvir integrativnog pristupa učenju i kreiranja nastavnih programa za učenje engleskog jezika pravne struke (ELP/LE) za akademske $i$ profesionalne potrebe u visokom obrazovanju. Integrativni pristup obuhvata niz međusobno povezanih jezičkih, diskursnih, metodoloških, pedagoških, psiholoških dimenzija, kao i mnogobrojne intradisciplinarne, multidisciplinarne, interdisciplinarne i transdisciplinarne aspekte. Analiza složene strukture, brojnih funkcija, dimenzija i aspekata ovog pristupa potkrepljena je prikazom teorijsko-metodološke literature i grafičkim prikazom integrativnih procesa. Prvi deo rada predstavlja konceptualni okvir integrativnog pristupa učenju u savremenom obrazovanju, pravničkom obrazovanju, i nastavi engleskog jezika struke (ESP/ELP). Drugi deo prikazuje konceptualni okvir i karakteristike raznih pristupa kreiranju nastavnih programa.Treći deo razmatra koncept, strukturu i funkcije integrisanog kurikuluma, kroz narativni i grafički prikaz multidimenzionalnih integrativnih procesa. Iskustva iz nastave Engleskog jezika pravne struke (ELP/LE) na Pravnom fakultetu u Nišu ukazuju da integrativni pristup nudi raznovrsne mogučnosti i praktična rešenja za kreiranje integrisanih nastavnih programa i holistički pristup učenju. U tom konterkstu, rad ima za cilj da podstakne saradnju svih relevantnih aktera (institucija, nastavnika, profesionalnih udruženja, poslodavaca, i studenta) u kreiranju integrativnih programa i projekata u oblasti prava i engleskog jezika pravne struke. Takvo partnerstvo bi doprinelo uspostavljnju aktivnog holističkog pristupa učenju, unapređenju globalnih kompetencija i transferabilnih veština, i promovisanju interdisciplinarnog i transdisciplinarnog pristupa pravničkom obrazovanju.
\end{abstract}

Ključne reči: engleski jezik struke (ESP), pravni engleski jezik (ELP/LE), integrativni pristup učenju, integrisani kurikulum, holistički pristup učenju. 